\title{
Does degradation from selective logging and illegal activities differently impact forest resources? A case study in Ghana
}

\author{
Gaia Vaglio Laurin ${ }^{(1-3)}$, \\ William D Hawthorne ${ }^{(2)}$, \\ Tommaso Chiti ${ }^{(1-3)}$, \\ Arianna Di Paola ${ }^{(1)}$, \\ Roberto Cazzolla Gatti ${ }^{(1)}$, \\ Sergio Marconi (3), \\ Sergio Noce ${ }^{(1)}$, \\ Elisa Grieco ${ }^{(1)}$, \\ Francesco Pirotti ${ }^{(4)}$, \\ Riccardo Valentini ${ }^{(1-3)}$
}

\begin{abstract}
Degradation, a reduction of the ecosystem's capacity to supply goods and services, is widespread in tropical forests and mainly caused by human disturbance. To maintain the full range of forest ecosystem services and support the development of effective conservation policies, we must understand the overall impact of degradation on different forest resources. This research investigates the response to disturbance of forest structure using several indicators: soil carbon content, arboreal richness and biodiversity, functional composition (guild and wood density), and productivity. We drew upon large field and remote sensing datasets from different forest types in Ghana, characterized by varied protection status, to investigate impacts of selective logging, and of illegal land use and resources extraction, which are the main disturbance causes in West Africa. Results indicate that functional composition and the overall number of species are less affected by degradation, while forest structure, soil carbon content and species abundance are seriously impacted, with resources distribution reflecting the protection level of the areas. Remote sensing analysis showed an increase in productivity in the last three decades, with higher resiliency to change in drier forest types, and stronger productivity correlation with solar radiation in the short dry season. The study region is affected by growing anthropogenic pressure on natural resources and by an increased climate variability: possible interactions of disturbance with climate are also discussed, together with the urgency to reduce degradation in order to preserve the full range of ecosystem functions.
\end{abstract}

Keywords: Tropical Forest, Remote Sensing, Degradation, Logging, Guild, Africa

\section{Introduction}

Forest degradation is defined as a reduction of the ecosystem's capacity to supply goods and services (FAO 2006). The West African forest belt is a biodiversity hotspot and a provider of fundamental ecosystem services, now degraded and reduced to a patchwork of forest fragments (CEPF 2003). Selective logging is possibly the primary cause of degradation in African forests with recognized impacts on carbon stocks (Cazzolla Gatti et al. 2015, Hawthor- ne et al. 2012) and fine root production (Ibrahima et al. 2010). In Ghana, concessions interest more than half of the reserves (Hawthorne \& Abu-Juam 1995). Impacts on resources other than carbon, such as tree species richness, diversity, functional composition, and productivity are less clear: they are difficult to quantify and vary with disturbance type, intensity and the area under analysis. With respect to biodiversity, varied research results were reported for disturbed forests in Ghana $\square$ (1) Impacts of Agriculture, Forests and Ecosystem Services Division, Euro-Mediterranean Center on Climate Change (IAFES-CMCC), v. Pacinotti 5, I-01100 Viterbo (Italy); (2) Department of Plant Sciences, University of Oxford, South Parks Road, Oxford OX13RB (United Kingdom); (3) Department for Innovation in Biological, Agro-Food and Forest Systems (DIBAF), University of Tuscia, I-01100 Viterbo (Italy); (4) Interdepartmental Research Center of Geomatics (CIRGEO), Land, Environment and Agriculture and Forestry Department (TESAF), University of Padova, I-35020 Legnaro, Padua (Italy)

\section{@ Francesco Pirotti (francesco.pirotti@unipd.it)}

Received: Jul 26, 2015 - Accepted: Nov 06, 2015

Citation: Vaglio Laurin G, Hawthorne WD, Chiti T, Di Paola A, Cazzolla Gatti R, Marconi S, Noce S, Grieco E, Pirotti F, Valentini R (2016). Does degradation from selective logging and illegal activities differently impact forest resources? A case study in Ghana. iForest 9: 354362. - doi: 10.3832/ifor1779-008 [online 2016-01-29]

Communicated by: Matteo Garbarino
(Asase et al. 2012, Poorter et al. 2008), and differentiated according to forest types (Bongers et al. 2009). For functional composition, a drought-driven shift toward drier forests has been reported by Fauset et al. (2012); while for net primary productivity, both climate-driven global increase (Nemani et al. 2003) and intact African forests biomass increase (Lewis et al. 2009) have been reported. Selective logging is also known to decrease productivity through larger trees removal (MEA 2005).

Our research investigates the effects of selective logging and illegal land use and resources extraction (here defined as "illegal activities") on forest resources, analyzing: forest structure and biomass; soil carbon content, tree richness and biodiversity, functional composition (guild and wood density); and productivity. With recent field data from two national parks and two forest reserves, we investigated whether the considered disturbance drivers differently affected forest resources, and the effectiveness of protection measures. With historical field data from the two reserves, we analyzed temporal changes in basal area and guild composition. Thirty years of remote sensing data allowed to study productivity trends in ten forests, mostly disturbed reserves, of southwestern Ghana and their relationships with precipitation, temperature and cloud cover. 
We tested the following four hypotheses: (i) impacts on forests' mean structure parameters, mean soil carbon (C) content, tree species' richness and diversity, and guilds and wood density, were stronger in the less protected areas; (ii) a significant increase in basal area occurred in the reserve (Bia) where logging activities stopped about two decades ago, while its sig nificant decrease occurred in the reserve affected by continuous illegal activities; (iii) a change in guilds composition in the direc tion of recovery occurred in the logged reserve, while a change toward furthe degradation occurred in the illegally disturbed one; (iv) the productivity in the ten forests increased over the last 30 years.

\section{Methodology}

We used 96 recent (2012-2013) and 94 his torical (1987 and 1991) field plots. In the recent dataset we collected species' name, diameter at breast height (DBH), and height $(\mathrm{H})$ information in four areas in a $\sim 150 \mathrm{~km}$ range on a south to north gradient (blue squares in Fig. S1 - Appendix 1): (i) the wet evergreen Ankasa National Park (NP), where logging was scarce and confined to the southern range; (ii) the moist evergreen Dadieso Forest Reserve (FR), surrounded by and including communities and cocoa farms which cause frequent illegal activities, such as timber extraction, hunting, gaps opening for cultivation, with presence of swampy zones; (iii) the moist evergreen Bia Resource Reserve (RR), selectively logged in 1980-90 and possibly also few years after; (iv) the moist semi-deciduous Bia National Park, where there are no logging records but fire, drought and elephants cause natural disturbance. Historical basal area and species records were collected by the Ghana Forestry Commission in one hectare plots: 59 in the Bia RR and 35 in Dadieso FR (dataset described in Hawthorne 1993). We collected orthophotos over the recent plots $(10 \mathrm{~cm}$ spatial resolution) in March 2012 with an aerial survey: we screened for signs of disturbance (logging trails, large gaps, and irregular canopy height), also reviewing information gathered from rangers and villagers to check the scarce disturbance official records. This was done by visual interpretation of images and also by interaction with the local community.

\section{Forest structure and guild data}

In the recent plots, DBH, $\mathrm{H}$, and species records were collected for trees having $\mathrm{DBH}>10 \mathrm{~cm}$. For the $1600 \mathrm{~m}^{2}$ plots, $400 \mathrm{~m}^{2}$ subplots were defined for sampling also trees with 10-20 cm DBH (Tab. S1 - Appendix 1). Height was collected using a laser hypsometer. In total, we sampled 11.79 ha and 1819 trees for $\mathrm{DBH}>20 \mathrm{~cm}$ and 8.51 ha and 1988 trees for $\mathrm{DBH}$ in $10-20 \mathrm{~cm}$ range (Tab. S2 - Appendix 1 ). In historical plots all trees above $30 \mathrm{~cm}$ DBH were sampled, and trees in the $10-30 \mathrm{~cm} \mathrm{DBH}$ range were collected in subplots of 0.2 ha.
Ordination scores for tree species (from Hall \& Swaine 1976, 1981) weighted by stem abundance were used to obtain scores for plots (Hawthorne 1996). This approach was used by Hawthorne (1995) to define a wet to dry gradient across Ghana. We ordinated plot data using the Nonmetric Multidimensional Scaling (NMS) statistical method using the PCORD ver. 6 software (McCune \& Mefford 2011).

From field records we calculated: wood density (WD, Global Wood Density Database - Chave et al. 2009); basal area (BA); above ground biomass (AGB, Chave et al. 2005); and tree guilds according to the Hawthorne (1993, 1995, 1996) classification, which identifies pioneer $(P)$, non-pioneer light-demanding (NPLD), shade-bearer (SB), and swamp-resistant (SR) species. Mean parameters difference among areas were tested in recent data using the MannWhitney (MW) U-test and the KolmogorovSmirnov (KS) test to additionally detect differences in the shape of distributions ( $\mathrm{Hol}$ lander \& Wolfe 1973). We preferred non-parametric statistics to account for non-normal distributions and outliers, represented by large old trees. The two DBH classes (10$20 \mathrm{~cm}$ and over $20 \mathrm{~cm}$ ) were tested separately at $95 \%$ confidence level, using the normal approximation to compute the $\mathrm{p}$ value, as samples are large in statistical terms. Distributions of $\mathrm{H}, \mathrm{DBH}$, and WD were estimated with a kernel density method based on the Gaussian kernel and using the Silverman's rule for bandwidth selection (Silverman 1986). For AGB and $\mathrm{BA}$, which are density dependent, we reported the normalized cumulative values per hectare. The following pairs were tested: Ankasa vs. Bia NPs, with limited disturbance occurrence; Bia NP vs. Bia RR, with different disturbance levels; and Dadieso FR vs. the other three areas. To detect changes between recent and historical data, the Mann-Whitney U-test was used for BA and the paired $z$-test for guild composition.

\section{Forest soil data}

Soil information was derived from eight $50 \times 50 \mathrm{~m}$ plots, two per forest area, located in close proximity to recent field plots. The soil field data used here are part of a larger soil data collection realized in the framework of the FP7 ERC Africa GHG project. As soil sensors were also used for project needs, it was decided to realize the soil survey just outside of the plots, to avoid problems to sensors and instruments that might be caused by the repeated passages of the tree survey team. Forest and soil plots were set up in homogeneous areas of small extent. In each plot, 10 samples of the organic horizon were randomly collected using a $40 \times 40 \mathrm{~cm}$ frame. In the mineral soil, 10 samples were collected in the topsoil (0-30 cm depth) and 10 in the subsoil (30-100 cm depth), using a cylinder (diameter $=5 \mathrm{~cm}$; height $=5 \mathrm{~cm}$ ) to determine the bulk density (Blake \& Hartge
1986). Samples were oven-dried $\left(60^{\circ} \mathrm{C}\right)$ to a constant weight and mineral soil was sieved at $2 \mathrm{~mm}$ to remove rock fragments; they were then ground in a ball mill to reach the highest homogenization possible and measured for total carbon via dry combustion (ThermoFinnigan Flash EA $112{ }^{\circledast} \mathrm{CHN}$, Gemini BV, Apeldoorn, Netherlands). To calculate the amount of carbon (C) each sample was corrected for the amount of rock fragments, and the soil organic carbon (SOC) stock calculated considering the bulk density, the $C$ concentration and the depth of each layer (Boone et al. 1999). Significant differences $(\alpha=0.001)$ between $C$ stocks of different soil layers were tested within each site and among sites by oneway analysis of variance and Tukey's test (Sokal \& Rohlf 1995).

\section{Species richness and biodiversity}

To avoid area-effects on results, richness and biodiversity indices were computed using recent data from subplots of same area, equal to $500 \mathrm{~m}^{2}$ in Ankasa NP and 400 $\mathrm{m}^{2}$ in all the other sites (Tab. S3 - Appendix 1). We adopted the Margalef's richness index because it is less sensitive to sampling efforts variations (Margalef 1958). Considering the high number of rare species, expressed as singletons, doubletons, and unique species (Magurran 2004), we adopted the Chao 1 index (Chao 1984) as a diversity measure, useful when datasets are skewed toward the low-abundance classes (Chao \& Shen 2003). We also reported the Coleman's rarefaction curve (Coleman et al. 1982) and the Shannon's evenness (Magurran 2004) for comparison purposes; however, both measures are sensitive to species abundance and may not be optimal for forests with many rare species (Gotelli \& Colwell 2001). Chao 1 index results were used to estimate the minimum sampling area needed to detect most of the species in each site $(A)$, using the area-species curve equation (eqn. 1 ):

$$
S=c A^{z}
$$

where $c$ and $z$ are parameters derived from the curves and $S$ is the Chao 1 index.

\section{Remote sensing and meteorological data}

The third generation of the GIMMS3g (Global Inventory Modelling and Mapping Studies) NDVI dataset has 15-day temporal frequency, $1 / 12^{\text {th }}$ of a degree spatial resolution and continuity from July 1981 to December 2011 (Zhu et al. 2013). We extracted NDVI values for 7 reserves and 3 national parks in southwestern Ghana (red stars in Fig. S1 - Appendix 1), using pixels with $>75 \%$ of their area inside the following reserves/parks: Anhwiaso FR, Ankasa NP, Atewa FR, Bia RR, Dadieso FR, Kakum NP, Krokosua NP, Subri FR, Subuma FR, and Tano FR. From the Climate Research Unit (CRU) 3.2 dataset (Harris et al. 2014) we extracted monthly rainfall, temperature, and cloud 
cover for the same period (1981-2011). We calculated monthly, seasonal and yearly basic statistics (mean, minimum, maximum, standard deviation) for NDVI time series, applied a 12-month moving-window average to visualize trends and oscillations, and detected anomalies subtracting the 30year averaged monthly values from the observations of that month, and then applying a 12-month moving-window average (Box et al. 2013). The observed differences in trends among sites were evaluated considering also their distance from the center of the wet evergreen Ghana ecological zone (FAO 1998). We calculated Spearman's correlation among NDVI and precipitation, cloud cover and temperature; and trends in CRU 3.2 and NDVI time series using the Seasonal Modified Kendall test (Hirsch \& Slack 1984) suited to treat data with seasonal cycles, and covariance evaluating the trend magnitude with slope estimation.

\section{Results}

Ordination of trees and disturbance evidences

The ordination scores attributed to plots corresponded to eight forest subcategories (Tab. S4 - Appendix 1) from Hall \& Swaine $(1976,1981)$. NMS results showed that our samples represent three different forest types found in the region along a primary latitudinal gradient: wet evergreen (Ankasa), moist evergreen (Dadieso) and moist semi-deciduous (Bia Reserve and $\mathrm{NP}$ ); a secondary gradient is present, accor-

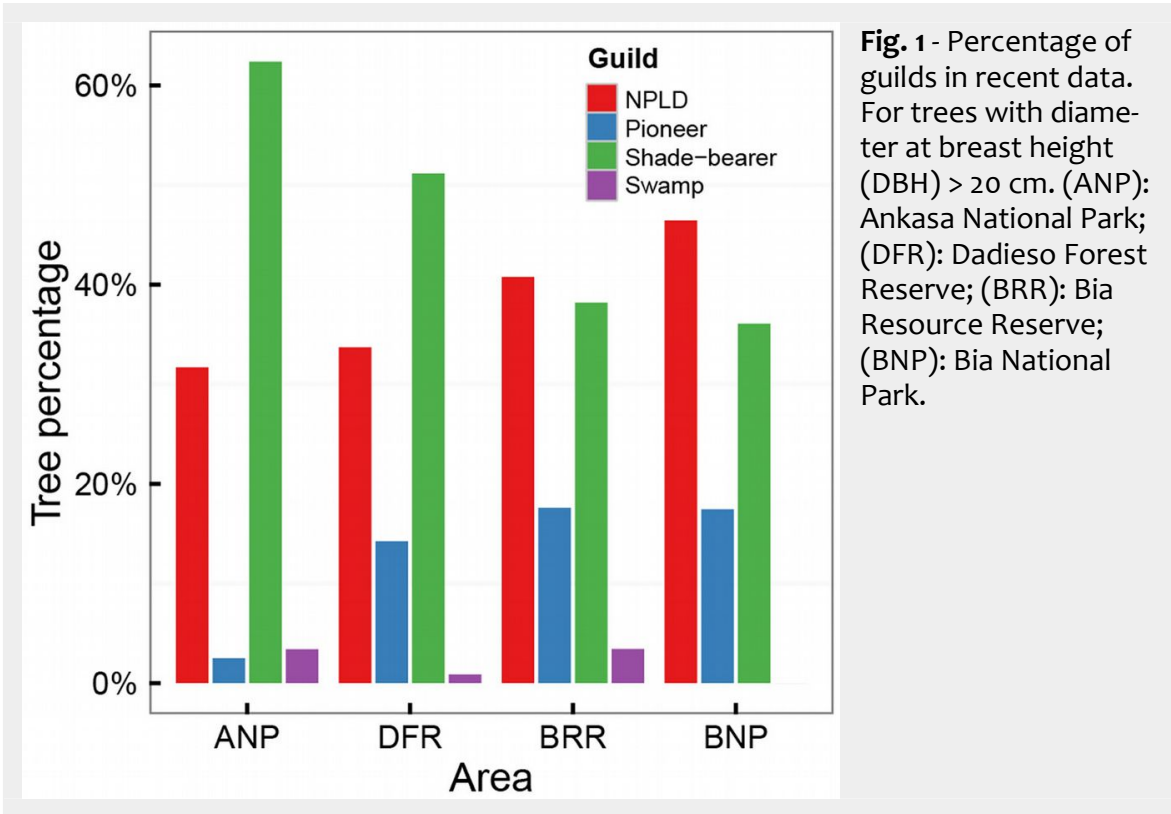

ding to soil moisture content or soil drai- cord was found. nage (Fig. 1). The orthophotos screening showed varied signs of disturbance. Ankasa showed no sign with closed and uniform canopy. In Bia NP, only uneven canopy height was detected in two plots. Logging scars, fallen trees, gaps and different canopy heights were observed in nine Bia RR plots. Even more signs were found in Dadieso (14 plots), where rangers, villagers and workers from timber companies reported frequent illegal activities (pers. comm. from March 2013), but no quantitative re-
Height, DBH, above ground biomass, and basal area

With recent data we performed descriptive statistics for $\mathrm{H}$ and $\mathrm{DBH}$ (Tab. S5 Appendix 1), AGB and BA normalized by area (Fig. 2, Tab. S6 - Appendix 1), and paired comparison tests at $95 \%$ confidence level (Tab. 1). For mean H, Ankasa resulted to be the tallest forest, followed by Bia NP, and then Dadieso and Bia Reserves; differences were significant between all pairs

Tab. 1 - Results of statistical pairwise comparison tests, 2012-2013 data. (ANP): Ankasa National Park; (DFR): Dadieso Forest Reserve; (BRR): Bia Resource Reserve; (BNP): Bia National Park. (H): height; (DBH): diameter at breast height; (WD): wood density; (BA): basal area; (AGB): above ground biomass; (MW): Mann-Whitney test; (KS): Kolmogorov-Smirnov test; $(*): p<0.05 ;(* *): p<0.01$; $(* * *): p<0.001$.

\begin{tabular}{|c|c|c|c|c|c|c|c|c|c|}
\hline \multirow{2}{*}{ Comparison } & \multirow{2}{*}{ Parameter } & \multicolumn{4}{|c|}{ DBH $10-20 \mathrm{~cm}$} & \multicolumn{4}{|c|}{$\mathrm{DBH}>20 \mathrm{~cm}$} \\
\hline & & MW stat & $\mathrm{p}$-value & KS stat & p-value & MW stat & $\mathrm{p}$-value & KS stat & $\mathrm{p}$-value \\
\hline \multirow{5}{*}{ BNP vs. BRR } & $\mathrm{H}$ & -0.88 & - & 0.10 & - & -4.44 & $* * *$ & 0.20 & $* * *$ \\
\hline & DBH & 0.84 & - & 0.06 & - & -4.23 & $* * *$ & 0.17 & $* * *$ \\
\hline & WD & -1.03 & - & 0.11 & - & 1.15 & - & 0.11 & $*$ \\
\hline & BA & 0.84 & - & 0.06 & - & -4.23 & $* * *$ & 0.17 & ** \\
\hline & AGB & -0.19 & - & 0.03 & - & -4.62 & $* * *$ & 0.20 & *** \\
\hline \multirow[t]{5}{*}{ BNP vs. ANP } & $\mathrm{H}$ & -14.30 & $* * *$ & 0.50 & $* * *$ & -9.34 & $* * *$ & 0.28 & *** \\
\hline & DBH & 0.63 & - & 0.05 & - & 1.90 & * & 0.11 & $* *$ \\
\hline & WD & -8.29 & $* * *$ & 0.36 & $* * *$ & -12.62 & $* * *$ & 0.44 & $* * *$ \\
\hline & BA & 0.63 & - & 0.05 & - & 1.90 & * & 0.11 & ** \\
\hline & AGB & -9.73 & $* * *$ & 0.30 & $* * *$ & -3.95 & $* * *$ & 0.17 & $* * *$ \\
\hline \multirow[t]{5}{*}{ DFR vs. BNP } & $\mathrm{H}$ & -0.27 & - & 0.08 & - & 2.22 & $* *$ & 0.14 & $* *$ \\
\hline & DBH & -2.63 & $* *$ & 0.14 & * & 4.56 & *** & 0.17 & $* * *$ \\
\hline & WD & -2.56 & * & 0.21 & $* * *$ & -3.17 & $* * *$ & 0.21 & $* * *$ \\
\hline & BA & -2.63 & $* *$ & 0.14 & * & 4.56 & $* * *$ & 0.17 & *** \\
\hline & $A G B$ & -2.43 & * & 0.15 & * & 3.36 & $* * *$ & 0.15 & $* * *$ \\
\hline \multirow[t]{5}{*}{ DFR vs. BRR } & $\mathrm{H}$ & 0.55 & - & 0.10 & - & -2.75 & $* * *$ & 0.15 & $* * *$ \\
\hline & DBH & -3.52 & $* * *$ & 0.16 & $* *$ & -0.33 & - & 0.05 & - \\
\hline & WD & -1.21 & - & 0.14 & $* *$ & -1.91 & * & 0.12 & * \\
\hline & BA & -3.52 & $* * *$ & 0.16 & $* *$ & -0.33 & - & 0.05 & - \\
\hline & AGB & -2.25 & $* *$ & 0.13 & * & -1.99 & $* *$ & 0.11 & * \\
\hline \multirow[t]{5}{*}{ DFR vs. ANP } & $\mathrm{H}$ & -15.33 & $* * *$ & 0.49 & $* * *$ & -12.65 & $* * *$ & 0.42 & $* * *$ \\
\hline & DBH & 4.29 & $* * *$ & 0.14 & $* * *$ & -3.90 & $* * *$ & 0.16 & $* * *$ \\
\hline & WD & -5.04 & ** & 0.19 & $* * *$ & -8.17 & $* * *$ & 0.30 & $* * *$ \\
\hline & BA & 4.29 & $* * *$ & 0.14 & $* * *$ & -3.90 & $* * *$ & 0.16 & $* * *$ \\
\hline & AGB & -6.75 & *** & 0.22 & *** & -9.01 & *** & 0.27 & *** \\
\hline
\end{tabular}


(a)

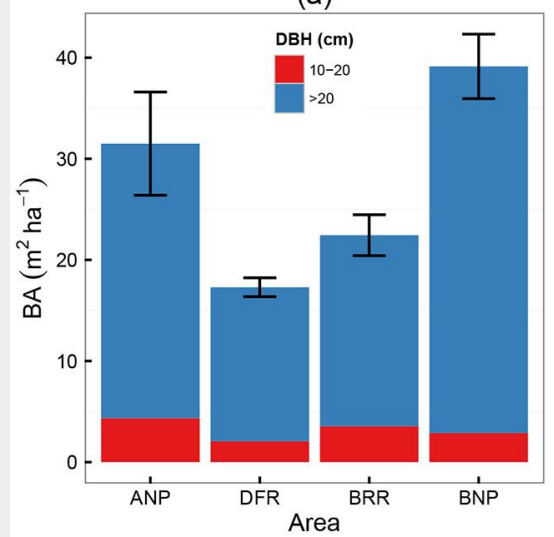

(b)

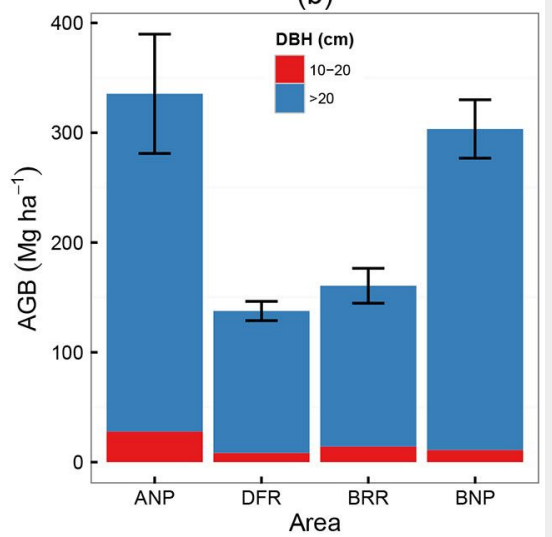

Fig. 2 - Recent above ground biomass (AGB) and basal area (BA) values. (ANP): Ankasa National Park; (DFR): Dadieso Forest Reserve; (BRR): Bia Resource Reserve; (BNP): Bia National Park.

Fig. 3 - Changes in basal area (BA), from past to present values, for trees with $\mathrm{DBH}>30 \mathrm{~cm}$. (DFR): Dadieso Forest Reserve; (BRR): Bia Resource Reserve.

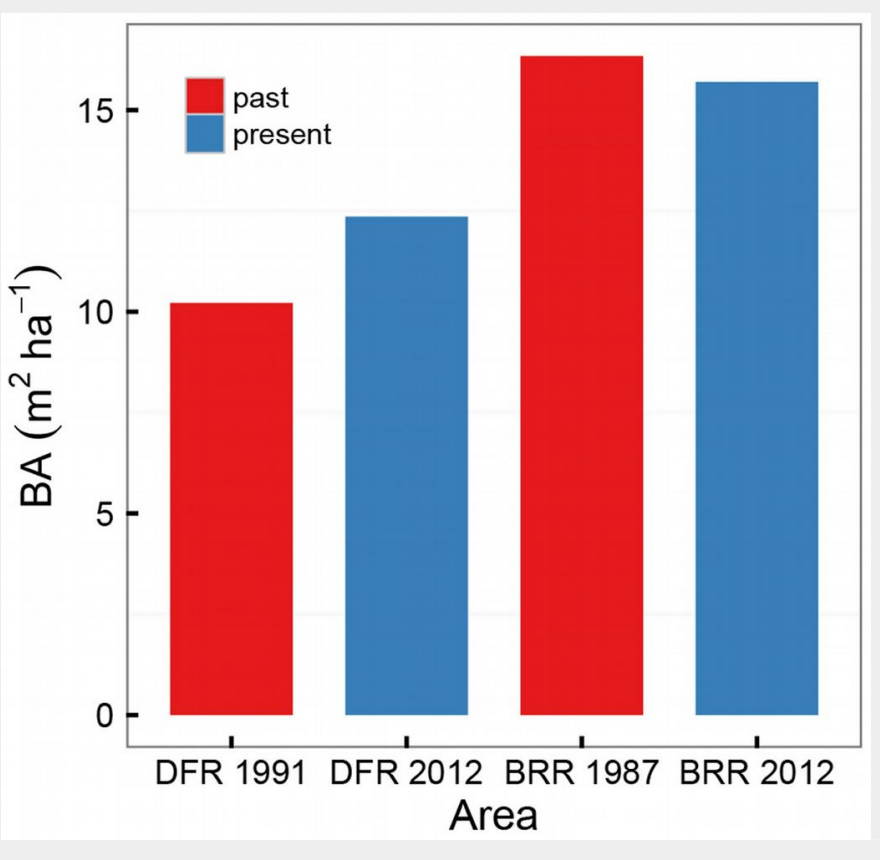

Fig. 4 - Changes in guild composition, from past to present values, for trees with $\mathrm{DBH}>30 \mathrm{~cm}$. (DFR): Dadieso Forest Reserve; (BRR): Bia Resource Reserve.

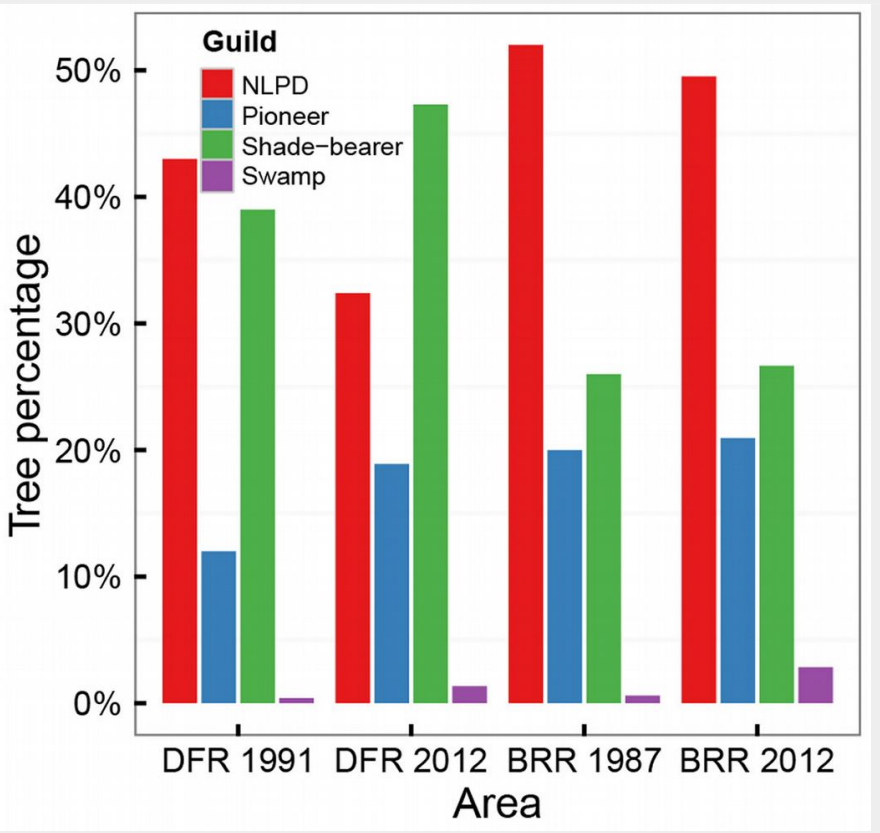

for trees with $\mathrm{DBH}>20 \mathrm{~cm}$, whereas for those within the DBH range $10-20 \mathrm{~cm}$ significant differences were found only between Ankasa and both Bia NP and Dadieso reserve. Regarding average AGB, Ankasa showed the highest value, followed by Bia NP, and Bia and Dadieso reserves; pairwise differences were always significant for both $\mathrm{DBH}$ ranges, except between the two Bia areas for $10-20 \mathrm{~cm}$ DBH trees.

Mean $\mathrm{BA}$ and mean $\mathrm{DBH}$ resulted higher in Bia NP, followed by Ankasa, Bia and Dadieso reserves; distributions were significantly different between Dadieso reserve and both Ankasa and Bia NPs for trees with $\mathrm{DBH}>20 \mathrm{~cm}$, and between Dadieso and the other three areas for trees in the $10-20 \mathrm{~cm}$ $\mathrm{DBH}$ range. The total number of trees per ha were: Ankasa 408; Dadieso 229; Bia reserve 368; Bia NP 352.

The analysis of these structural parameters confirmed our first hypothesis (i) of higher impacts on mean forest structure values in the less protected areas where selective logging or illegal disturbance occurred.

\section{Wood density and guild composition}

Mean WD analysis showed for both DBH ranges the highest in Ankasa and the lowest in Bia NP; differences in distributions were significant between Ankasa and both Bia NP and Dadieso, and between Dadieso and Bia NP.

Percentages of trees per guild for $\mathrm{DBH}$ $>20 \mathrm{~cm}$ showed that, from Ankasa to Bia $\mathrm{NP}$, pioneer and non-pioneer light-demanding species increased, while shade-bearer species decreased (Fig. 1, Tab. S7 - Appendix 1); for the $10-20 \mathrm{~cm}$ DBH range the pattern was similar. Swamp species were too scarce for evaluation.

The results from WD and guild composition analysis are in disagreement with the first hypothesis (i) of stronger impacts in the less protected reserves. Instead, WD and guild composition followed the latitudinal gradient.

\section{Temporal changes in basal area and guild composition}

The BA from historical data totaled 15.96 $\mathrm{m}^{2} \mathrm{ha}^{-1}$ in Dadieso and $23.82 \mathrm{~m}^{2} \mathrm{ha}^{-1}$ in Bia reserves (Tab. S8 - Appendix 1). The BA change over time, tested for trees with $\mathrm{DBH}>30 \mathrm{~cm}$ to account for differences in sampling thresholds in the surveys, was not significant for any of the areas (Fig. 3). This is in contrast to what was defined in the second hypothesis (ii), namely a recovery in BA for Bia NP, where logging activities ceased two decades ago, and a decrease for Dadieso, still affected by illegal activities. For Bia Reserve, the difference in $\mathrm{BA}$ from the neighboring Bia NP is more than $50 \%$, revealing very degraded conditions; the even lower BA in Dadieso indicates a highly degraded forest.

Historical guild data (Tab. S8 - Appendix 1) showed for that time a prevalence in Dadieso (trees $>30 \mathrm{~cm} \mathrm{DBH}$ ) of non-pioneer 
light-demanding species, followed by shade-bearer, pioneer and swamp species; in the $10-30 \mathrm{~cm}$ DBH range, the first two guilds were instead inverted in order. In Bia, for both DBH classes, the prevalent guild was non-pioneer light-demanding, followed by shade bearer, pioneer, and swamp-resistant.

Guild change over time, tested for trees with $\mathrm{DBH}>30 \mathrm{~cm}$ (Fig. 4), was not significant for any guild in Bia, contrary to the shift toward recovery predicted by our third hypothesis (iii). For Dadieso, a significant increase in pioneer and shade-bearer species was found, with significant decrease of non-pioneer light-demanding species; swamp-resistant trees were too limited for testing. The further Dadieso degradation predicted by our third hypothesis (iii) is in contrast with the increase of shadow-bearer species.

Overall, Bia recovery has not occurred after two decades, with unaltered BA and guilds composition. In Dadieso BA conditions are unchanged, while guild data only partially support our initial hypothesis.

\section{Species richness and biodiversity}

The Margalef index (Tab. 2) indicated an increasing species richness moving southward from Bia to Ankasa NPs. This result contradicts our first hypothesis (i) regarding a stronger impact in less protected areas. The richness distribution follows the latitudinal gradient as found for WD and guilds composition. The Chao 1 index (Tab. 2) was higher in NPs, and confirms our first hypothesis. For minimum sampling area, we obtained 3.02 and 3.27 ha respectively for Ankasa and Bia NPs, while for Bia and Dadieso Reserves 1.28 and 3.06 ha, respectively. We reported Shannon's evenness in Tab. 2 and Coleman's rarefaction curve in Fig. S2 - Appendix 1.
Tab. 2 - Biodiversity indices calculated per area. (ANP): Ankasa National Park; (DFR): Dadieso Forest Reserve; (BRR): Bia Resource Reserve; (BNP): Bia National Park.

\begin{tabular}{lcccc}
\hline $\begin{array}{l}\text { Biodiversity indices } \\
(\mathrm{DBH}>\mathbf{1 0} \mathrm{cm})\end{array}$ & ANP & DFR & BRR & BNP \\
\hline Area $\left(\mathrm{m}^{2}\right)$ & 17000 & 18400 & 8800 & 10000 \\
Number of species & 147 & 120 & 94 & 84 \\
\# of individuals & 841 & 402 & 290 & 335 \\
Singletons & 54 & 48 & 39 & 37 \\
Dubletons & 22 & 22 & 17 & 7 \\
Uniques & 57 & 55 & 43 & 37 \\
Margalef's richness & 21.68 & 19.85 & 16.40 & 14.28 \\
Chao 1 \pm st.dev. & $213.19 \pm 24.29$ & $172.23 \pm 20.09$ & $138.58 \pm 19.11$ & $181.49 \pm 49.83$ \\
Shannon's Evenness & 0.85 & 0.91 & 0.91 & 0.88 \\
\hline
\end{tabular}

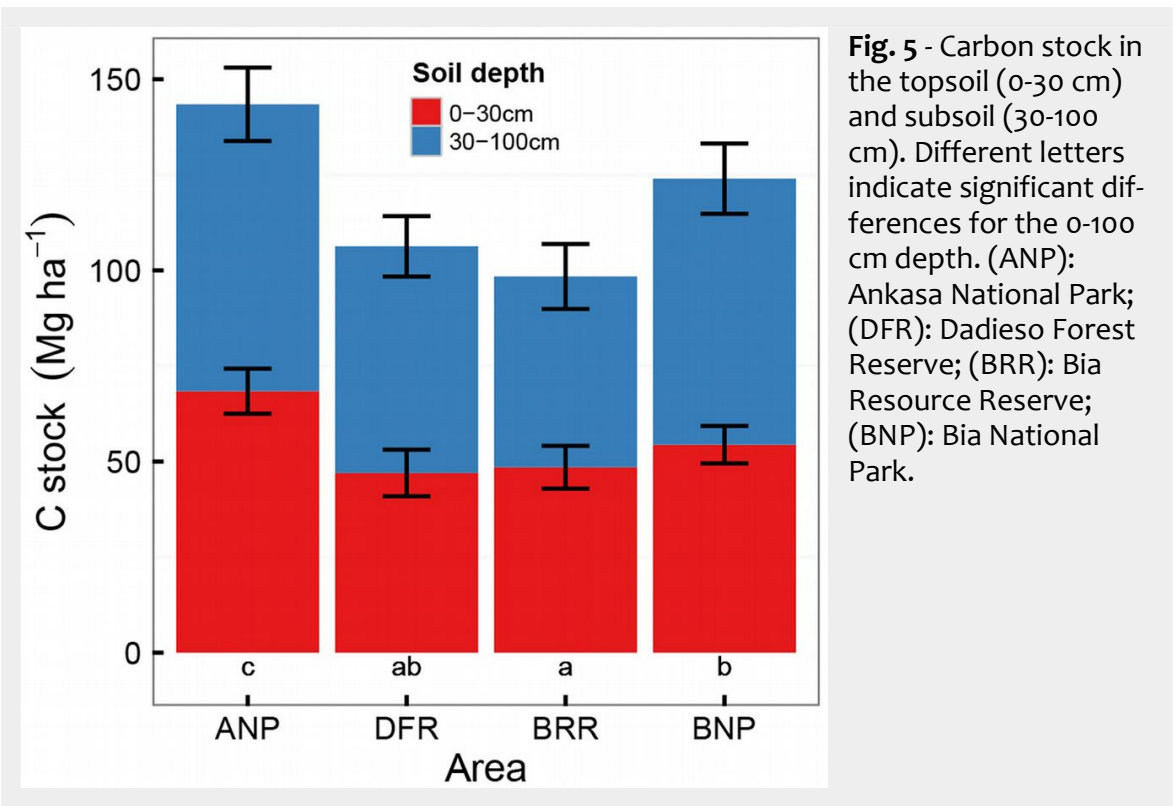

Soil carbon content

rence between the two parks. In Dadieso

Fig. 5 illustrates the SOC results. In the the $C$ concentration was only significantly topsoil, the $\mathrm{C}$ concentration in the Bia lower than in Ankasa. Compared to the reserve was significantly lower $(p<0.001)$ topsoil which stores roughly half of the than in Ankasa and Bia NPs, with no diffe- total SOC stock stored down to 1 meter,

Tab. 3 - Seasonal Modified Kendall tests for NDVI and climate data from ten forested areas in Ghana. Z-test values, p-values and slopes are displayed. (FR): Forest Reserve; (NP): National Park; (RR): Resource Reserve. (NDVI): Normalized Difference Vegetation Index; (-): non significant; $(*): p<0.05 ;(* *): p<0.01 ;(* * *)$ : $p<0.001$.

\begin{tabular}{|c|c|c|c|c|c|c|c|c|c|}
\hline Variable & Site & Z & $\mathrm{p}$-value & slope & Variable & Site & Z & p-value & slope \\
\hline \multirow[t]{10}{*}{ NDVI } & Ankasa NP & 3.166 & $* * *$ & 0.003 & Precipitation & Ankasa NP & 1.775 & * & 4.789 \\
\hline & Subri FR & 2.560 & $* *$ & 0.002 & & Subri FR & 2.424 & $* *$ & 6.767 \\
\hline & Tano FR & 3.331 & *** & 0.003 & & Tano FR & 2.079 & ** & 5.500 \\
\hline & Kakum NP & 2.515 & $* *$ & 0.003 & & Kakum NP & 2.268 & $* *$ & 6.070 \\
\hline & Subuma FR & 3.966 & $* * *$ & 0.004 & & Subuma FR & 2.247 & $* *$ & 5.527 \\
\hline & Dadieso FR & 2.269 & * & 0.002 & & Dadieso FR & 1.839 & * & 4.373 \\
\hline & Anwhiaso FR & 2.149 & * & 0.002 & & Anwhiaso FR & 2.247 & * & 5.257 \\
\hline & Krokosua NP & 3.071 & *** & 0.002 & & Krokosua NP & 2.223 & * & 4.091 \\
\hline & Bia RR & 2.054 & * & 0.002 & & Bia RR & 2.176 & * & 3.572 \\
\hline & Atewa FR & 1.902 & * & 0.001 & & Atewa FR & 0.778 & - & 1.928 \\
\hline \multirow[t]{10}{*}{ Temperature } & Ankasa NP & 2.515 & ** & 0.015 & Cloud cover & Ankasa NP & 1.302 & - & - \\
\hline & Subri FR & 2.795 & $* *$ & 0.016 & & Subri FR & 1.174 & - & - \\
\hline & Tano FR & 2.286 & * & 0.014 & & Tano FR & 1.739 & * & 0.261 \\
\hline & Kakum NP & 2.969 & *** & 0.017 & & Kakum NP & 0.681 & - & 0.167 \\
\hline & Subuma FR & 2.412 & $* *$ & 0.008 & & Subuma FR & 1.227 & - & 0.250 \\
\hline & Dadieso FR & 2.321 & $* *$ & 0.014 & & Dadieso FR & 1.771 & * & 0.294 \\
\hline & Anwhiaso FR & 2.412 & ** & 0.013 & & Anwhiaso FR & 1.227 & - & 0.250 \\
\hline & Krokosua NP & 2.234 & * & 0.013 & & Krokosua NP & 1.834 & * & 0.366 \\
\hline & Bia RR & 2.331 & ** & 0.014 & & Bia RR & 1.952 & * & 0.364 \\
\hline & Atewa FR & 2.545 & ** & 0.014 & & Atewa FR & 0.417 & - & 0.048 \\
\hline
\end{tabular}


Tab. 4 - Spearman's correlation values between NDVI time series and monthly climate data for ten forested areas in Ghana. (NDVI): Normalized Difference Vegetation Index.

\begin{tabular}{lccc}
\hline \multirow{2}{*}{ Site } & \multicolumn{3}{c}{ Spearman's correlation $(\boldsymbol{\rho})$} \\
\cline { 2 - 4 } & Cloud cover & Precipitation & Temperature \\
\hline Ankasa NP & -0.51 & 0.40 & 0.28 \\
Subri FR & -0.44 & 0.25 & 0.33 \\
Tano FR & -0.44 & 0.48 & 0.31 \\
Kakum NP & -0.43 & 0.32 & 0.24 \\
Subuma FR & -0.54 & 0.49 & 0.28 \\
Dadieso FR & -0.52 & 0.48 & 0.31 \\
Anhwiaso FR & -0.55 & 0.43 & 0.25 \\
Krokosua NP & -0.57 & 0.42 & 0.28 \\
Bia FR & -0.60 & 0.40 & 0.19 \\
Atewa FR & -0.47 & 0.40 & 0.22 \\
\hline
\end{tabular}

the $C$ concentrations in the subsoil considerably decreased: no detectable differences were observed among the sites. The significantly higher $\mathrm{C}$ stocks found in Ankasa and Bia NPs support the first hypothesis (I) of stronger impacts in less protected sites.

\section{Remote sensing and meteorological data}

NDVI trends over 30 years were analyzed. Monthly averaged NDVI values in the ten forested areas remarked the two distinct productive seasons (Fig. S3 - Appendix 1). Oscillations in 30-year NDVI temporal series showed consistency among the areas, but different magnitude (Fig. S4 - Appendix 1). The Seasonal Modified Kendall tests (Tab. 3) indicated a significant NDVI increase for all the areas, in accordance to our fourth hypothesis (iv) of a forest productivity increase along the last 30 years. Also precipitation (with the exception of Atewa FR, an upland rainforest) and temperature significantly increased, while cloud cover data showed a significant positive trend only for areas located in the most northwest range (Tano, Dadieso and Bia Reserves, and Krokosua NP). Positive and negative NDVI fluctuations are more marked in areas closer to the wet evergreen zone.

Spearman's $\rho$ correlation was tested between NDVI time series and climate parameters (Tab. 4), with higher $\rho$ values found using 12 months of precipitation, 5 of cloud cover (June-October), and 3 of temperature (July-September). For all but one area (Tano FR) the highest correlation was found with cloud cover, with $\rho$ values ranging from -0.43 to -0.60 , followed by precipitation ( $\rho$ from 0.25 to 0.49 ) and temperature ( $\rho$ from 0.19 to 0.33 ).

\section{Discussion}

\section{Degradation impacts and protection status}

The $C$ stocks and BA of Bia and Dadieso reserves were reduced by $50 \%$ or more compared to the Ankasa and Bia NP; significant reduction was also observed for structural parameters $(\mathrm{H}, \mathrm{DBH})$. The illegal activities reported for the Dadieso reserve had impacts similar or even worse than se- lective logging in Bia. Even if we could collect only unofficial records, Hansen et al. (2012) evaluated that in Ghana the informal lumber sector, driven primarily by domestic consumption, represents $80 \%$ of the market, and is six times the annual allowable cut. A balance between forest regrowth and persistent illegal activities, possibly coupled with natural disturbance, may explain the lack of BA change along time observed for Dadieso.

The complete absence of recovery of BA in the Bia reserve might be explained if severe logging occurred after historical data collection, possibly coupled with climate natural disturbance, which had been reported for the drier Ghana tropical range by Owusu \& Waylen (2009). In this case multiple stresses may have limited until now the ability of the forest to recover. Recovery is linked to the frequency of past disturbance events as well as their intensity and type, with some research estimating hundreds to a thousand years for a complete recovery of fragmented forests (Liebsch et al. 2008). Recovery from selective logging might be much longer than that estimated through growth models, as previously observed in Ghana by Hawthorne et al. (2012), as forest biomass can continue to decline after logging ceases due to delayed effects on tree mortality (Blanc et al. 2009). The BA change observed in the Bia reserve poses a warning for the sustainability of current selective logging schemes.

Bia NP had a significantly higher mean $\mathrm{DBH}$ and BA with respect to Ankasa NP; tree density was higher in Ankasa, but larger stems were recorded in Bia. Moist forests can have more favorable water conditions, more nutrients and lower light competition compared with drier forests, as observed by Hall \& Swaine (1981) in Gha$\mathrm{na}$, thus explaining the presence of such very large trees in Bia.

With respect to SOC, the two NPs showed a $\mathrm{C}$ stock in the $0-100 \mathrm{~cm}$ depth similar or higher than the average reported for a series of Oxisols from Western and Central Africa by Batjes (2008) and Henry et al. (2009). In contrast, results from the two reserves showed SOC stocks significantly lower than these values. Logging, even if selective, promotes SOC decomposition by creating gaps in the canopy cover and reducing the inputs of organic $C$ to soil (Yanai et al. 2003, Li et al. 2015). All logging activities leave behind large amounts of slash which decomposes, and, combined with an increased mortality of residual trees, increases ecosystem heterotrophic respiration and $\mathrm{CO}_{2}$ emissions for years following harvest (Blanc et al. 2009, Huang \& Asner 2010). The topsoil, where most of the tropical forests $C$ is stored, is the layer more prone to changes following disturbance, as observed by Chiti et al. (2014) in Western Ghana. Our results are not consistent with what reported by Asase et al. (2012) for both Bia areas, as our Bia NP values are much higher. This discrepancy may be due to the low number of samples (4) collected in the aforementioned study.

For species diversity, results from the Chao 1 index indicated that the two NPs have much higher species diversity than the reserves. This is agreement with the results of a meta-analysis by Gibson et al. (2011), who showed that forest degradation has an overwhelmingly detrimental effect on tropical biodiversity; however, the authors reported that selecting logging causes smaller impact compared to other disturbance types. The area needed to sample diversity was higher in the NPs, with the about 3 ha value being far from the 1-1.5 ha commonly suggested as an adequate sampling size (Alder \& Synnott 1992, Lanly 1981); such data could represent an indication for planning field diversity studies in this region.

According to our study, NPs were more effective in conserving forest structure, soil $C$ content, and biodiversity. The evenness component of species diversity is especially important for assessing the effects of degradation, as higher richness can be observed in disturbed areas as a result of an increased number of pioneer species. A reduced species evenness caused by disturbance represents alone an indication of biodiversity loss. This result adds to the existing evidence that selective logging has severe impacts in African forests (Bedigian 1998, Hall et al. 2003, Hawthorne et al. 2012). However, it is evident that this protection cannot be granted to all the forest fragments of the region, while on the edges of NPs, such as Ankasa, economic problems are causing an increase in anthropogenic pressure (Damnyag et al. 2013). In order to avoid further depletion of forest resources within and around protected areas, viable management solutions, such as the European Union FLEGT (Forest Law Enforcement, Governance and Trade) facility should be strengthened (RamcilovicSuominen et al. 2010), as well as smart and cost-effective restoration approaches (Sasaki et al. 2011).

\section{Forest variables less influenced by disturbance}

In this study arboreal richness distribu- 
tion followed the latitudinal gradient. According to the Intermediate Disturbance Hypothesis, higher richness values are found in moderately disturbed areas (Molino \& Sabatier 2001). Bongers et al. (2009) found in Ghana that richness is less sensitive to disturbance in wet than in dry forests. Norris et al. (2010) in a West African review study observed that, although in some instances overall species richness increased in disturbed sites, the richness of endemic species tended to decline. Species richness is also known to increase with rainfall amount in this region (Hall \& Swaine 1981).

Functional composition, namely WD and guilds, was also distributed according to the latitudinal gradient; the percentage of pioneer species, an indicator of disturbance, was not higher in the more degraded areas.

These results indicate that both richness and functional composition are shaped by climate parameters and less affected by the disturbance types we considered.

\section{Regional forest productivity and \\ climate variable trends}

Previous studies showed the ability of GIMMS3g to capture productivity dynamics (Wang et al. 2014, Zhu \& Southworth 2013). Our result of NDVI increasing trends is in agreement with the increase in carbon storage observed for African intact tropical forests (Lewis et al. 2009), as well as with the increase in net primary production recorded at a global scale (Nemani et al. 2003). As most (7) of the ten sites we considered were reserves affected by multiple disturbances, our results supports the view that productivity can be enhanced by fast growing species that are abundant in disturbed sites (Carreño-Rocabado et al. 2012). The magnitude of oscillations in NDVI decreased with increasing distance from the wetter tropical forest type center (Fig. S4 Appendix 1), congruent with observations indicating that drier forests are characterized by higher resiliency to changes and have $50-75 \%$ of the productivity of wetter forest types (Ewel 1977, Murphy \& Lugo 1986).

The increasing trend in precipitation and temperature resulting from 30 years of CRU 3.2 dataset analysis is opposite of the precipitation decrease observed by Fauset et al. (2012) and Owusu \& Waylen (2009). We explain this difference considering that the CRU datasets up to version 3.10.01 were affected by a bug in precipitation data (http://www.cru.uea.ac.uk/cru/data/h $\mathrm{rg} /$ ). Moreover, we examined a different period (1981-2011) with respect to the aforementioned studies, and the area we analyzed is much toward south than that of Fauset et al. (2012). Finally, the CRU cells considered in this study are not so close to stations used in Owusu \& Waylen (2009).

Previous studies reported different results about which climate variables mostly influence forest productivity (Dong et al.
2012, Graham et al. 2003, Pau et al. 2013). However, it is known that light availability plays a key role in limiting photosynthesis (Mulkey et al. 1996). Seasonal productivity changes have been already observed in the dry tropics, as a result of climate change, but usually are not investigated as often or intensely as long-term changes (Feng et al. 2013). The strongest negative correlation of NDVI with cloud cover during the short dry season, that was higher than that with precipitation, stresses the importance of examining changes in seasonal patterns beside long-term changes, especially in "bimodal" seasonal forests.

\section{Forest resources conservation in a changing climate}

In mostly undisturbed forests of Ghana, Fauset et al. (2012) found that prolonged drought led to a consequent change in functional composition toward drought-resistant species, with increase in pioneers and decrease in shadow-bearers. These shifts are similar to those caused by selective logging, which also increases pioneers and decreases shadow-bearers through gap openings. Unless there is certainty of absence of disturbance (including illegal activities), it is difficult to understand what contributes more to a guild change. Our historical data were collected in two disturbed areas, but the lack of guild change found in the Bia reserve and the increase in shadow-bearer species observed in Dadieso do not support a functional composition change in our study sites. Bongers et al. (2009) found that in Ghana the response in guild composition to disturbance intensity changed according to forest type, being significant only in drier forests. It is possible that the forests located in the zone we focused are more resilient to functional changes. However, climate change is a concerning issue in West Africa, with predictions still uncertain, especially for precipitation (Paeth et al. 2011). If considering climate alone, deciduous and evergreen forests might expand in the future, but human impacts will play a critical role in the future of forest resources (Heubes et al. 2011). New technologies such as laser scanning for forests (Pirotti 2010, 2011, Santoro et al. 2013) will enable a better monitoring of changes to support decision and policies. Our results call for additional functional change studies focused on the possible varied responses of different forest types.

\section{Conclusions}

Overall, the impacts observed in reserves are alarming, especially considering that most of the West African forests are under this low protection status. Even the NPs of this region might be threatened by growing anthropogenic pressure, and lack of resources and buffer zones (IUCN 2010). Community-based resource management projects have been implemented in Ghana, but several issues hamper their full effec- tiveness (Damnyag et al. 2013). It is urgent to strengthen these approaches and properly value the range of services provided by forests, including agro-forestry systems that could generate $C$ credits (Norris et al. 2010). Selectively logged and degraded forests remain critical for the conservation of biodiversity and $C$ storage potential, once adequately protected (Lindsell \& Klop 2013). Forest productivity increase is an opportunity for recovery that is very important to seize. This translates into the need to reconsider the sustainability of selective logging schemes, to improve controls in forests, to strengthen viable forest management alternatives, providing more incentives for conservation through international programs.

\section{Acknowledgments}

We acknowledge the EC FP7 ERC grant Africa GHG \#247349. The funding source was not involved in any part of the manuscript preparation. We are grateful to the Ghana Forestry Commission staff, to Justice Mensah, and to all the field collaborators. We thank Prof. Ranga Mynani and Dr. Zeichuan Zhu for providing the GIMMS3g dataset. G.V.L. thanks the EU for supporting the $\mathrm{BACl}$ project funded by the EU's 692 Horizon 2020 Research and Innovation Programme under grant agreement 6401 76. None of the authors has any conflict of interest.

\section{References}

Alder D, Synnott TJ (1992). Permanent sample plot techniques for mixed tropical forest. Tropical Forest Papers 25: 124-145. [online] URL: http://agris.fao.org/agris-search/search.do? recordID $=G B 2012106028$

Asase A, Asitoakor B, Ekpe P (2012). Linkages between tree diversity and carbon stocks in unlogged and logged West African tropical forests. International Journal of Biodiversity Science Ecosystem Services Management 8: 37-41. - doi: 10.1080/21513732.2012.707152

Batjes NH (2008). Mapping soil carbon stocks of Central Africa using SOTER. Geoderma 146: 5865. - doi: 10.1016/j.geoderma.2008.05.006 Bedigian D (1998). Ecology of an African rain forest logging in Kibale and the conflict between conservation and exploitation. Economic Botany 52: 87-98. - doi: 10.1007/BF02861299

Blake GR, Hartge KH (1986). Bulk density In: "Methods of soil analysis: Part 1. Physical and mineralogical methods" (Klute A ed). Soil Science Society of America, American Society of Agronomy, Wisconsin, USA, pp. 363-375.

Blanc L, Echard M, Herault B, Bonal D, Marcon E, Chave J, Baraloto C (2009). Dynamics of aboveground carbon stocks in a selectively logged tropical forest. Ecological Applications 19: 13971404. - doi: 10.1890/08-1572.1

Bongers F, Poorter L, Hawthorne WD, Sheil D (2009). The intermediate disturbance hypothesis applies to tropical forests but disturbance contributes little to tree diversity. Ecology letters 12: 798-805. - doi: 10.1111/j.1461-0248.2009. 01329.x

Boone RD, Grigal DF, Sollins P, Ahrens RJ, Arm- 
strong DE (1999). Soil sampling preparation archiving and quality control In: "Standard soil methods for long-term ecological research" (Robertson G, Coleman D, Bledsoe C, Sollins P eds). Oxford University Press, New York, USA, pp. 3-28. [online] URL: http://cedarcreek.umn. edu/biblio/fulltext/t1823.pdf

Box GEP, Jenkins GM, Reinsel GC (2013). Time series analysis: forecasting and control. John Wiley and Sons, Hoboken, New Jersey, USA, pp. 598. [online] URL: http://link.springer.com/ chapter/10.1057/9781137291264_6

Carreño-Rocabado G, Peña-Claros M, Bongers F, Alarcón A, Licona J-C, Poorter L (2012). Effects of disturbance intensity on species and functional diversity in a tropical forest. Journal of Ecology 100: 1453-1463. - doi: 10.1111/j.1365-2745.20 12.02015.x

Cazzolla Gatti R, Castaldi S, Lindsell J, Coomes D, Marchetti M, Maesano M, Di Paola A, Paparella F, Valentini R (2015). The impact of selective logging and clearcutting on forest structure tree diversity and above-ground biomass of African tropical forests. Ecological Research 30 : 119-132. - doi: $10.1007 / \mathrm{s} 11284-014-1217-3$

CEPF (2003). Guinean forests of West Africa biodiversity hotspot: upper Guinean forest briefing book. Critical Ecosystem Partnership Fund, Washington DC, USA, pp. 51.

Chao A (1984). Nonparametric estimation of the number of classes in a population. Scandinavian Journal of Statistics 11: 265-270. [online] URL: http://www.jstor.org/stable/4615964

Chao A, Shen TJ (2003). Nonparametric estimation of Shannon's index of diversity when there are unseen species in sample. Environmental and Ecological Statistics 10 (4): 429-443. - doi: 10.1023/A:1026096204727

Chave J, Andalo C, Brown S, Cairns MA, Chambers JQ, Eamus D, Fölster $\mathrm{H}$, Yamakura $\mathrm{T}$ (2005). Tree allometry and improved estimation of carbon stocks and balance in tropical forests. Oecologia 145: 87-99. - doi: 10.1007/s004 42-005-0100-x

Chave J, Coomes D, Jansen S, Lewis SL, Swenson NG, Zanne AE (2009). Towards a worldwide wood economics spectrum. Ecology Letters 12: 351-366. - doi: 10.1111/j.1461-0248.2009.01285.X

Chiti T, Grieco E, Perugini L, Rey A, Valentini R (2014). Effect of the replacement of tropical forests with tree plantations on soil organic carbon levels in the Jomoro district Ghana. Plant and Soil 375: 47-59. - doi: 10.1007/s11104-01 3-1928-1

Coleman BD, Mares MA, Willig MR, Hsieh YH (1982). Randomness area and species richness. Ecology 63: 1121-1133. - doi: 10.2307/1937249

Damnyag L, Saastamoinen O, Blay D, Dwomoh FK, Anglaaere LC, Pappinen A (2013). Sustaining protected areas: identifying and controlling deforestation and forest degradation drivers in the Ankasa Conservation Area in Ghana. Biological Conservation 165: 86-94. - doi: 10.1016/j. biocon.2013.05.024

Dong SX, Davies SJ, Ashton PS, Bunyavejchewin S, Supardi MNN, Kassim AR, Tan S, Moorcroft PR (2012). Variability in solar radiation and temperature explains observed patterns and trends in tree growth rates across four tropical forests. Proceedings of the Royal Society B: Biological Sciences 279: 3923-3931. - doi: 10.109 8/rspb.2012.1124

Ewel JJ (1977). Differences between wet and dry successional tropical ecosystems. GeoEcoTrop 1: 103-117.

FAO (1998). Country profile: Ghana. FID/CP/GHA Rev 3, Food and Agriculture Organization of the United Nations, Rome, Italy, pp. 37.

FAO (2006). Global forest resources assessment 2005. Progress towards sustainable forest management. FAO Forestry Paper no 147, Food and Agriculture Organization of the United Nations, Rome, Italy, pp. 321.

Fauset S, Baker TR, Lewis SL, Feldpausch TR, Affum-Baffoe K, Foli EG, Hamer KC, Swaine MD (2012). Drought-induced shifts in the floristic and functional composition of tropical forests in Ghana. Ecology Letters 15: 1120-1129. - doi: 10.1111/j.1461-0248.2012.01834.x

Feng X, Porporato A, Rodriguez-Iturbe I (2013). Changes in rainfall seasonality in the tropics. Nature Climate Change 3: 811-815. - doi: 10.1038/ nclimate1907

Gibson L, Lee TM, Koh LP, Brook BW, Gardner TA, Barlow J, Peres CA, Bradshaw CJA, Laurance WF, Lovejoy TE, Navjot S (2011). Primary forests are irreplaceable for sustaining tropical biodiversity. Nature 478: 378-381. - doi: 10.1038/ nature10425

Gotelli NJ, Colwell RK (2001). Quantifying biodiversity: Procedures and pitfalls in the measurement and comparison of species richness. Ecology Letters 4: 379-391. - doi: 10.1046/j.1461-024 8.2001.00230.x

Graham EA, Mulkey SS, Kitajima K, Phillips NG, Wright SJ (2003). Cloud cover limits net $\mathrm{CO}_{2}$ uptake and growth of a rainforest tree during tropical rainy seasons. PNAS 100: 572-576. - doi: 10.1073/pnas.0133045100

Hall JB, Swaine MD (1976). Classification and ecology of closed-canopy forest in Ghana. Journal of Ecology 64: 913-1001. - doi: 10.2307/2258 816

Hall JB, Swaine MD (1981). Distribution and ecology of vascular plants in a tropical rain forest: forest vegetation in Ghana. Springer Netherlands, Dordretch, The Netherlands, pp. 383. [online] URL: http://www.cabdirect.org/abstrac ts/19810673016.html

Hall JS, Harris DJ, Medjibe V, Ashton PMS (2003). The effects of selective logging on forest structure and tree species composition in a Central African forest: implications for management of conservation areas. Forest Ecology and Management 183: 249-264. - doi: 10.1016/S0378-1127 (03)00107-5

Hansen CP, Damnyag L, Obiri BD, Carlsen K (2012). Revisiting illegal logging and the size of the domestic timber market: the case of Ghana. International Forestry Review 14: 39-49. doi: 10.1505/146554812799973181

Harris I, Jones PD, Osborn TJ, Lister DH (2014). Updated high-resolution grids of monthly climatic observations - the CRU TS310 Dataset. International Journal of Climatology 34: 623642. - doi: 10.1002/joc.3711

Hawthorne WD (1993). Forest regeneration after logging: findings of a study in the Bia South Game Production Reserve in Ghana. ODA Forestry Series 3: 52-65. [online] URL: http://www.cabdirect.org/abstracts/199506130 97.html
Hawthorne WD (1995). Ecological profiles of Ghanaian forest trees. Tropical Forestry Papers no 29, Oxford Forestry Institute, Oxford, UK, pp. 345. [online] URL: http://www.cabdirect. org/abstracts/19950616640.html

Hawthorne WD (1996). Holes and the sums of parts in Ghanaian forest: regeneration scale and sustainable use. Proceedings of the Royal Society of Edinburgh Section B - Biological Sciences 104: 75-176. - doi: 10.1017/S02697270000 06126

Hawthorne W, Abu-Juam M (1995). Forest protection in Ghana with particular reference to vegetation and plant species. International Union for Conservation of Nature, Gland, Switzerland, pp. 202. [online] URL: http://books. google.com/books?id=SDvefe6R-2QC

Hawthorne WD, Sheil D, Agyeman VK, Abu Juam M, Marshall CM (2012). Logging scars in Ghanaian high forest: towards improved models for sustainable production. Forest Ecology and $\mathrm{Ma}$ nagement 271: 27-36. - doi: 10.1016/j.foreco.20 12.01.036

Henry M, Valentini R, Bernoux M (2009). Soil carbon stocks in ecoregions of Africa. Biogeosciences Discussions 6: 797-823. - doi: 10.5194/bgd6-797-2009

Heubes J, Kühn I, König K, Wittig R, Zizka G, Hahn $K$ (2011). Modelling biome shifts and tree cover change for 2050 in West Africa. Journal of Biogeography 38: 2248-2258. - doi: 10.1111/j.13 65-2699.2011.02560.x

Hirsch RM, Slack JR (1984). A nonparametric trend test for seasonal data with serial dependence. Water Resources Research 20: 727-732. doi: 10.1029/WR020ioo6p00727

Hollander M, Wolfe D (1973). Nonparametric statistical methods. John Wiley and Sons, New York, USA, pp. 848.

Huang M, Asner GP (2010). Long-term carbon loss and recovery following selective logging in Amazon forests. Global Biogeochemical Cycles 24: GB3028. - [online] URL: http://onlinelibrary. wiley.com/doi/10.1029/2009GB003727/full Ibrahima A, Mvondo ZE, Ntonga JC (2010). Fine root production and distribution in the tropical rainforests of south-western Cameroon: effects of soil type and selective logging. iForest 3: 130-136. - doi: 10.3832/iforo549-003

IUCN (2010). Parks and reserves of Ghana: management effectiveness assessment of protected areas. International Union for Conservation of Nature, Gland, Switzerland, pp. 56.

Lanly J (1981). Manual of forest inventory; with special reference to mixed tropical forests. FAO Forestry Paper 27, FAO, Rome, Italy, pp. 200.

Lewis SL, Lopez-Gonzalez G, Sonké B, Affum-Baffoe K, Baker TR, Ojo LO, Phillips OL, Reitsma JM, White L, Wöll H (2009). Increasing carbon storage in intact African tropical forests. Nature 457: 1003-1006. - doi: 10.1038/nature07771 Liebsch D, Marques MCM, Goldenberg R (2008). How long does the Atlantic rain forest take to recover after a disturbance? Changes in species composition and ecological features during secondary succession. Biological Conservation 141: 1717-1725. - doi: 10.1016/j.biocon.2008.04.013 Li Y, Xia Y, Lei Y, Deng Y, Chen H, Sha L, Cao M, Deng $X$ (2015). Estimating changes in soil organic carbon storage due to land use changes using a modified calculation method. iForest 8 : 
45-52. - doi: 10.3832/ifor1151-007

Lindsell JA, Klop E (2013). Spatial and temporal variation of carbon stocks in a lowland tropical forest in West Africa. Forest Ecology and Management 289: 10-17. - doi: 10.1016/j.foreco.2012 .09 .045

Magurran AE (2004). Measuring biological diversity. African Journal of Aquatic Science 29: 285286. - doi: $10.2989 / 16085910409503825$

Margalef DR (1958). Information theory in ecology. Year-book of the Society for General Systems Research 3: 36-71.

McCune B, Mefford M (2011). PC-ORD. Multivariate analysis of ecological data (version 6). MjM Software, Gleneden Beach, Oregon, USA, pp. 28. [online] URL: http://www.pcord.com/PBook let.pdf

MEA (2005). Ecosystems and human well-being: current state and trends. Island Press, Washington, DC, USA, pp. 917.

Molino JF, Sabatier D (2001). Tree diversity in tropical rain forests: a validation of the intermediate disturbance hypothesis. Science 294: 1702-1704. - doi: 10.1126/science.1060284

Mulkey SS, Kitajima K, Wright SJ (1996). Plant physiological ecology of tropical forest canopies. Trends in Ecology Evolution 11: 408-412. doi: 10.1016/0169-5347(96)10043-4

Murphy PG, Lugo AE (1986). Ecology of tropical dry forest. Annual Review of Ecology and Systematics 17: 67-88. - doi: 10.1146/annurev.es.17. 110186.000435

Nemani RR, Keeling CD, Hashimoto H, Jolly WM, Piper SC, Tucker CJ, Myneni RB, Running SW (2003). Climate-driven increases in global terrestrial net primary production from 1982 to 1999. Science 300: 1560-1563. - doi: 10.1126/scien ce. 1082750

Norris K, Asase A, Collen B, Gockowksi J, Mason J, Phalan B, Wade A (2010). Biodiversity in a forest-agriculture mosaic-the changing face of West African rainforests. Biological Conservation 143: 2341-2350. - doi: 10.1016/j.biocon.2009. 12.032

Owusu K, Waylen P (2009). Trends in spatio-temporal variability in annual rainfall in Ghana (1951-2000). Weather 64: 115-120. - doi: 10.1002/ wea. 255

Paeth $\mathrm{H}$, Hall NMJ, Gaertner MA, Alonso MD, Moumouni S, Polcher J, Ruti PM, Fink AH, Gosset $M$, Rummukainen $M$ (2011). Progress in regional downscaling of west African precipitation. Atmospheric Science Letters 12: 75-82. doi: 10.1002/asl.306

Pau S, Wolkovich EM, Cook BI, Nytch CJ, Regetz J, Zimmerman JK, Wright S (2013). Clouds and temperature drive dynamic changes in tropical flower production. Nature Climate Change 3: 838-842. - doi: 10.1038/nclimate1934

Pirotti F (2010). Assessing a template matching approach for tree height and position extraction from lidar-derived canopy height models of Pinus Pinaster stands. Forests 1: 194-208. doi: 10.3390/f1040194

Pirotti F (2011). Analysis of full-waveform LiDAR data for forestry applications: a review of investigations and methods. iForest 4: 100-106. - doi: 10.3832/iforo562-004

Poorter L, Hawthorne W, Bongers F, Sheil D (2008). Maximum size distributions in tropical forest communities: relationships with rainfall and disturbance. Journal of Ecology 96: 495504. - doi: 10.1111/j.1365-2745.2008.01366.x

Ramcilovic-Suominen S, Gritten D, Saastamoinen O (2010). Concept of livelihood in the FLEGT voluntary partnership agreement and the expected impacts on the livelihood of forest communities in Ghana. International Forestry Review 12: 361-369. - doi: 10.1505/ifor.12.4.361

Sasaki N, Asner GP, Knorr W, Durst PB, Priyadi HR, Putz FE (2011). Approaches to classifying and restoring degraded tropical forests for the anticipated REDD+ climate change mitigation mechanism. iForest 4: 1-6. - doi: 10.3832/iforo5 56-004

Santoro F, Tarantino E, Figorito B, Gualano S, D'Onghia AM (2013). A tree counting algorithm for precision agriculture tasks. International Journal of Digital Earth 6 (1): 94-102. - doi: 10.10 80/17538947.2011.642902

Silverman B (1986). Density estimation for statistics and data analysis. Chapman and Hall/CRC, Boca Raton, FL, USA, pp. 171.

Sokal RR, Rohlf FJ (1995). Biometry: the principles and practice of statistics in biological research. Freeman, San Francisco, USA, pp. 776.

Wang J, Dong J, Liu J, Huang M, Li G, Running SW, Smith WK, Harris W, Saigusa N, Kondo $H$, Xiao X (2014). Comparison of gross primary productivity derived from GIMMS NDVI3g GIMMS and MODIS in Southeast Asia. Remote Sensing 6: 2108-2133. - doi: 10.3390/rs6032108

Yanai RD, Currie WS, Goodale CL (2003). Soil carbon dynamics after forest harvest: an ecosystem paradigm reconsidered. Ecosystems 6: 197212. - doi: 10.1007/s10021-002-0206-5

Zhu L, Southworth J (2013). Disentangling the relationships between net primary production and precipitation in Southern Africa savannas using satellite observations from 1982 to 2010. Remote Sensing 5: 3803-3825. - doi: 10.3390/ rs5083803

Zhu Z, Bi J, Pan Y, Ganguly S, Anav A, Xu L, Samanta A, Piao S, Nemani RR, Myneni RB (2013).
Global data sets of vegetation leaf area index (LAI) $3 g$ And fraction of photosynthetically active radiation (FPAR) $3 g$ derived from global inventory modeling and mapping studies (GIMMS) normalized difference vegetation index (NDVI3g) for the period 1981 to 2011. Remote Sensing 5: 927-948. - doi: 10.3390/rs5020927

\section{Supplementary Material}

\section{Appendix 1}

Fig. S1 - The study areas. Includes sites with field data (four blue squares), and sites where remote sensing data (ten red stars) were used.

\section{Fig. S2 - Coleman rarefaction curve.}

Fig. S3 - 30-year averaged monthly NDVI values in 10 forested areas in Ghana.

Fig. S4 - Anomalies in 30-year NDVI time series for ten forests in Ghana. Sites are ordered according to increasing distance (from top left to bottom right) from the wet evergreen ecological center.

Tab. S1 - Recent plots information.

Tab. S2 - Total area sampled and number of trees in recent data.

Tab. S3 - Total area sampled and number of trees used for richness and diversity analysis; data are from subplots of $500 \mathrm{~m}^{2}$ for Ankasa, and $400 \mathrm{~m}^{2}$ for the other areas.

Tab. S4 - Nonmetric Multidimensional Scaling (NMS) ordination of data in eight subcategories.

Tab. S5 - Statistics of mean tree height, diameter at breast height (DBH), and wood density parameters per DBH class, 2012-13 data.

Tab. S6 - Basal area and above ground biomass (AGB) values, 2012-13 data.

Tab. S7 - Percentage of guilds per diameter at breast height (DBH) class, recent data.

Tab. S8 - Historical basal area and guilds data for DFR and BRR.

Link: Vaglio_1779@supploo1.pdf 